\title{
ARIZONA GROUND-WATER QUALITY
}

\author{
By Lester R. Kister and Dean B. Radtke \\ U.S. Geological Survey \\ and
}

Chuck Graf, Arizona Department of Health Services

U.S. Geological Survey Open-File Report 87-0713 


\section{DEPARTMENT OF THE INTERIOR \\ DONALD PAUL HODEL, Secretary}

\section{U.S. GEOLOGICAL SURVEY}

Dallas L. Peck, Director

For additional information:

Chief Hydrologist

U.S. Geological Survey

407 National Center

Reston, VA 22092
For sale by:

U.S. Geological Survey

Books and Open-File Reports Section Federal Center

Box 25425

Denver, Colorado 80225

Use of trade names in this report is for descriptive purposes only and does not constitute endorsement by the U.S. Geological Survey 


\section{FOREWORD}

This report contains summary information on ground-water quality in one of the 50 States, Puerto Rico, the Virgin Islands, or the Trust Territories of the Pacific Islands, Saipan, Guam, and American Samoa. The material is extracted from the manuscript of the 1986 National Water Summary, and with the exception of the illustrations, which will be reproduced in multi-color in the 1986 National Water Summary, the format and content of this report is identical to the State ground-water-quality descriptions to be published in the 1986 National Water Summary. Release of this information before formal publication in the 1986 National Water Summary permits the earliest access by the public. 


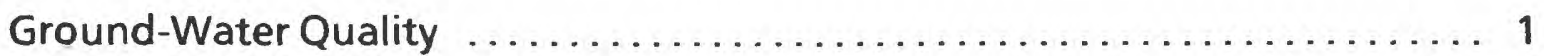

Water-Quality in Principal Aquifers $\ldots \ldots \ldots \ldots \ldots \ldots \ldots \ldots \ldots \ldots \ldots \ldots \ldots \ldots \ldots$

Background Water Quality $\ldots \ldots \ldots \ldots \ldots \ldots \ldots \ldots \ldots \ldots \ldots$

Basin and Range Lowlands $\ldots \ldots \ldots \ldots \ldots \ldots \ldots \ldots \ldots \ldots$

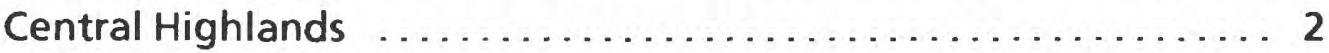

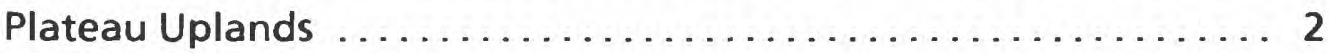

Effects of Land Use on Water Quality ..................... 2

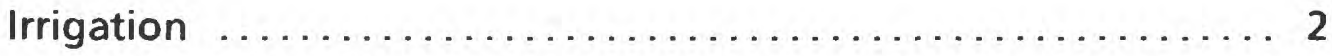

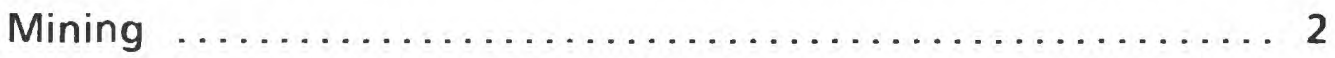

Urbanization ..................................... 3

Waste Disposal ................................ 3

Potential for Water-Quality Changes ..................... 3

Ground-Water-Quality Management $\ldots \ldots \ldots \ldots \ldots \ldots \ldots \ldots \ldots \ldots \ldots \ldots \ldots \ldots$

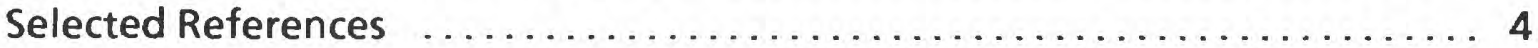

Illustrations

Figure 1.--Selected geographic feature and 1985 population distribution in Arizona.

Figure 2.--Principal aquifers and related water-quality data in Arizona.

Figure 3.--Selected waste sites and ground-water quality information in Arizona. 


\section{Arizona Ground-Water Quality}

In Arizona, ground-water-quality problems are a major concern because ground water is the principal source for public supply. In 1983, about two-thirds of the water used in the State was derived from ground-water sources (U.S. Geological Survey, 1985a), and ground water supplied 65 percent of the population (fig. 1). In 1983, about 73 percent of the ground water withdrawn was used for agriculture; the remainder was used for public, industrial, domestic, and stock purposes. According to Kister (1973), about 95 percent of all ground-water withdrawals in the State were from alluvial aquifers in the Basin and Range lowlands water province (fig. 2A2).

Ground-water-quality problems exist locally at several locations throughout the State. With some exceptions, ground water generally meets drinking-water standards established by the Arizona Department of Health Services (ADHS) and the U.S. Environmental Protection Agency (1986a,b). In the nine major areas of groundwater withdrawal within the State (fig. $2 A 2$ ), the median concentration of dissolved solids is less than the State's recommended maximum contaminant level of $500 \mathrm{mg} / \mathrm{L}$ (milligrams per liter). In all areas, the median concentration of nitrate plus nitrite (as nitrogen) is less than the maximum contaminant level of $10 \mathrm{mg} / \mathrm{L}$ for drinking water. Degradation of water quality in many areas throughout the State is associated with urbanization, irrigation, and leachates from mine tailings and surface impoundments.

Five hazardous-waste sites in the State (fig. $3 A$ ) require monitoring of ground-water quality under the Resource Conservation and Recovery Act (RCRA) of 1976. In addition to the RCRA sites, five sites are included in the U.S. Environmental Protection Agency's (EPA) National Priorities List (NPL) of hazardous-waste sites (U.S. Environmental Protection Agency, 1986c). These five sites require additional evaluation under the Comprehensive Environmental Response, Compensation, and Liability Act (CERCLA) of 1980. Four additional sites have been proposed for inclusion on the NPL by the EPA. Contamination of ground water has been detected near all RCRA and CERCLA sites in Arizona. Arizona has six military facilities where hazardous-waste sites have been identified under the Installation Restoration Program (IRP).

The ADHS and the Arizona Department of Water Resources (ADWR) operate ground-water-quality monitoring networks primarily as part of special studies or near known or suspected contaminated areas. Water-quality data have been collected by the U.S. Geological Survey as part of various projects through the years. These data are stored and maintained in the National Water Data Storage and Retrieval System (WATSTORE) data base, which is maintained by the Geological Survey. With enactment of the Arizona Environmental Quality Act of 1986, new efforts will be made by the State to develop and implement ground-water-quality monitoring networks.

\section{WATER QUALITY IN PRINCIPAL AQUIFERS}

The principal aquifers in Arizona (fig. 2A1) consist of unconsolidated alluvium (alluvial aquifers), consolidated sedimentary rocks (sandstone aquifers), and crystalline igneous and metamorphic rocks (bedrock aquifers). The occurrence and quality of water in the principal aquifers are controlled by the geology and physiography in three distinct water provinces (fig. 2A2)-Basin and Range lowlands, Central highlands, and Plateau uplands (Kister, 1973). Background water quality in the principal aquifers will be described according to the water province in which they occur.

\section{BACKGROUND WATER QUALITY}

A graphic summary of selected water-quality variables compiled from the U.S. Geological Survey's WATSTORE data base is presented in figure $2 C$. The summary is based on dissolved-solids, hardness, nitrate plus nitrite (as nitrogen), fluoride, and sulfate analyses of water samples collected from 1965 to 1985 from the principal aquifers in 13 selected ground-water basins (fig. 2A2). Percentiles of these variables are compared to national standards that specify the maximum concentration or level of a contaminant in drinking-water supply as established by the U.S. Environmental Protection Agency (1986a,b). The primary maximum contaminant level standards are health related and are legally enforceable. The secondary maximum contaminant level standards apply to esthetic qualities and are recommended guidelines. The primary drinking-water standards include a maximum concentration of 10 $\mathrm{mg} / \mathrm{L}$ nitrate (as nitrogen) and $4 \mathrm{mg} / \mathrm{L}$ fluoride; the secondary drinking-water standards include maximum concentrations of 500 $\mathrm{mg} / \mathrm{L}$ dissolved solids, $2 \mathrm{mg} / \mathrm{L}$ fluoride, and $250 \mathrm{mg} / \mathrm{L}$ sulfate. The statistics do not consider changes in water quality with depth or areal distribution.

\section{Basin and Range Lowlands}

The Basin and Range lowlands water province is characterized by isolated north- to northwest-trending mountain ranges separated by broad alluvial basins. The alluvial aquifers in this province are composed of deposits derived from surrounding mountains. Older sedimentary and crystalline rocks (bedrock aquifers) generally are denser and more cemented than the younger overlying deposits and yield usable water only where extensively fractured or faulted (U.S. Geological Survey, 1985b, p. 136).

Alluvial aquifers in this province are the most productive aquifers in the State. About 95 percent of the ground water withdrawn in Arizona is from these alluvial aquifers (Kister, 1973). Quality of water in the alluvial aquifers varies with location and depth within the province. The local lithology and mineralogy of the alluvial sediments affect the chemical composition of the water. In some places, dissolved-solids concentrations decrease with increasing depth, which results in a change in water type. In Pinal County, the Willcox and Tucson areas, and the western part of Salt River Valley basin (figs. 1A, 2A2), the water type changes from a calcium bicarbonate to a sodium bicarbonate at greater depths. According to Robertson (1986, p. 69), concentrations of naturally occurring fluoride, barium, arsenic, and chromium in the Basin and Range lowlands alluvial aquifers range from trace amounts to 5 to 10 times the State and Federal maximum contaminant levels of 4 $\mathrm{mg} / \mathrm{L}, 1 \mathrm{mg} / \mathrm{L}, 0.05 \mathrm{mg} / \mathrm{L}$, and $0.010 \mathrm{mg} / \mathrm{L}$, respectively.

Dissolved-solids concentrations in water from the alluvial aquifers (fig. $2 C$, basins $1-10$ ) range from less than 100 to more than $40,000 \mathrm{mg} / \mathrm{L}$, but generally are less than $1,000 \mathrm{mg} / \mathrm{L}$. However, median dissolved-solids concentrations in basins 2, 3, 4 , and 9 and median sulfate concentrations in basins 2 and 9 exceed the recommended EPA secondary drinking-water standards of $500 \mathrm{mg} / \mathrm{L}$ and $250 \mathrm{mg} / \mathrm{L}$, respectively (fig. $2 \mathrm{C}$ ). The median concentrations of nitrate plus nitrite (as nitrogen) and fluoride in water from the alluvial aquifers in the Basin and Range lowlands do not exceed EPA primary drinking-water standards (fig. 2, basins 1-10). Water in alluvial aquifers in basins 2,3 , and 9 is generally hard or very hard (greater than $120 \mathrm{mg} / \mathrm{L}$ as calcium carbonate). 


\section{Central Highlands}

The Central highlands water province is a mountainous area that separates the Basin and Range lowlands from the Plateau uplands. The province consists principally of rugged, sharply pinnacled ranges and volcanic mountains. Igneous, metamorphic, and consolidated sedimentary rocks (bedrock aquifers) form the core of the province and only where rocks are fractured or faulted are there usable amounts of water. A few valleys are filled with alluvium that provides minor amounts of water (U.S. Geological Survey, $1985 \mathrm{~b}$, p. 136). Data indicate that ground water in the province generally contains less than $1,000 \mathrm{mg} / \mathrm{L}$ of dissolved solids although some springs yield saline water to streams (Kister, 1973).

\section{Plateau Uplands}

In the Plateau uplands water province, most of the water is derived from consolidated sedimentary rocks (Sandstone aquifers) - mainly the Coconino, Navajo, and Dakota Sandstones. Because of relatively sparse population, only about 3 percent of the total ground water withdrawn in Arizona is from the aquifers in this province. Ground water is used mostly by scattered farms and rural homesites, industrial sites, and a few population centers such as Flagstaff, Holbrook in central Navajo County, and the White Mountains recreational areas in southern Apache County (fig. 1A).

Median concentrations of dissolved solids, nitrate plus nitrite (as nitrogen), fluoride, and sulfate in water from the sandstone aquifers in the Plateau uplands do not exceed EPA primary or secondary drinking-water standards for these constituents (fig. $2 C$, basins 11-13). However, dissolved-solids concentrations in water from the sandstone aquifers range from 90 to more than $12,000 \mathrm{mg} / \mathrm{L}$. In the Coconino Sandstone, concentrations of dissolved solids range from less than $500 \mathrm{mg} / \mathrm{L}$ in the northeastern part of the province to more than $25,000 \mathrm{mg} / \mathrm{L}$ north of the Little Colorado River in the south-central part. The Navajo Sandstone yields water that generally contains less than $1,000 \mathrm{mg} / \mathrm{L}$ dissolved solids throughout the province. Water from the Dakota Sandstone contains from 1,000 to $3,000 \mathrm{mg} / \mathrm{L}$ of dissolved solids.

In addition to the sandstone aquifers, water is obtained from alluvial aquifers and the voids within the crystalline igneous and metamorphic rocks. However, the amount is very small.

Principal constituents in ground water in the Plateau uplands province are calcium, sodium, bicarbonate, sulfate, and chloride. These constituents form five general water types-calcium bicarbonate, sodium bicarbonate, sodium sulfate, calcium sulfate, and sodium chloride. Water that contains dissolved-solids concentrations of less than $500 \mathrm{mg} / \mathrm{L}$ generally is calcium bicarbonate or sodium bicarbonate type water. Water that contains more than 500 $\mathrm{mg} / \mathrm{L}$ generally is sodium sulfate, calcium sulfate, or sodium chloride type water. Gradations occur between chemical types. Very mineralized water that contains dissolved-solids concentrations greater than $3,000 \mathrm{mg} / \mathrm{L}$ generally is a sodium sulfate, calcium sulfate, or sodium chloride type water. Minor constituents in ground water in the Plateau uplands, such as fluoride, nitrate, magnesium, silica, and iron, vary considerably and, except for fluoride and nitrate, the concentrations meet water-quality criteria for most uses (Kister, 1973).

\section{EFFECTS OF LAND USE ON WATER QUALITY}

In some areas, changes in ground-water quality are caused by (1) recirculation of salts in irrigation water, (2) leachates from mining operations, (3) runoff from urban areas, (4) disposal of toxic wastes, and (5) leachates from landfills (fig. 3). According to the Arizona Department of Health Services (1986), contamination of water in 347 wells has been documented. Of these wells, 115 contained pesticides, 173 contained volatile organic compounds, and 59 exceeded maximum contaminant levels of such compounds as ${ }^{*}$ ethylene dibromide (EDB), 1,2-dibromo-3-chloropropane (DBCP), tetrachloroethylene (PCE), and trichloroethylene (TCE).

\section{Irrigation}

In 1983 the Pima Association of Governments (PAG) completed a study of part of the upper Santa Cruz River basin alluvial aquifer, Pima County (basin 8, fig. 2A2), which determined the effects of different types of land uses on the quality of ground water. Results showed that agricultural irrigation caused an increase in the amount of nitrate in the aquifer (Pima Association of Governments, 1983a).

Significant changes in concentrations of dissolved solids (as much as $500 \mathrm{mg} / \mathrm{L}$ ) in ground water have occurred since 1910 in an irrigated agricultural area in the Willcox basin, Cochise County basin 10, (fig. 2A2). These changes may have been caused by removal of saline water from the shallow alluvial aquifer by irrigation pumping and by movement of the saline water in the shallow aquifer toward extensively pumped areas where large water-level declines have been recorded. In the Willcox basin alluvial aquifer, a significant increase in dissolved solids has occurred as a result of recharge of irrigation water containing salts in areas where depth to water is less than 100 feet (Kister and others, 1966). In another part of the Willcox basin aquifer, water contains elevated levels of dissolved solids which presently range from 501 to $1,000 \mathrm{mg} / \mathrm{L}$ where water levels have risen about 13 feet since 1910 (Mann and others, 1978). In both instances, the increase in dissolved-solids concentrations may have resulted from recirculation of salts from irrigation water to the water table. In many other places overlying the Willcox basin aquifer, salt from irrigation water is also being deposited in the soil, but it may be many years before salt reaches the saturated zone because the depth to water table is more than 200 feet below land surface.

In 1979 and 1980, the ADHS sampled 170 wells for DBCP, a soil fumigant, in Maricopa and Yuma Counties and found 59 wells that contained water with detectable concentrations (Arizona Department of Health Services, written commun., 1984). Four public and 55 privately owned water-supply wells were affected. The four public wells were removed from service and all private well owners were notified of the results. DBCP, a pesticide used in Arizona since 1955 for control of nematodes on citrus, cotton, and other crops, was banned for some uses in 1977 because it was linked to human male sterility and was carcinogenic in laboratory animals. Use of DBCP reached a peak in 1979 when 495,800 pounds were applied for pest control. In 1984, the ADHS sampled 92 wells across the State for DBCP and 43 wells for EDB. Preliminary results indicate a significant incidence of contamination (Arizona Department of Health Services, written commun., 1984). EDB is used as a soil fumigant for controlling nematodes and as an anti-knock additive in leaded gasoline. EDB was banned for most uses in 1983 after it was found to be carcinogenic in laboratory animals. Since the mid-1950's, from 150,000 to 200,000 pounds per year of EDB have been used in Arizona agriculture (Arizona Department of Health Servies, written commun., 1984).

\section{Mining}

According to a study by the PAG of ground water and tailings ponds in the upper Santa Cruz River basin (basin 8, fig. 2A2), the quality of water in the alluvial aquifer has been degraded locally by recharge from tailings ponds. Analyses of well water downgradient from tailings ponds showed increases in hardness, sulfate, dissolved solids, and other constituents (Pima Association of Governments, 1983b, p. 13). The results indicate a possibility of future contamination of public water-supply wells in the area.

For at least the past 40 years, ground-water quality in the Pinal Creek basin near Globe has been degraded also as the result of seepage of acidic mining and milling process solutions (En- 
virologic Systems, Inc., 1983). According to Eychaner and Stollenwerk (1985, p. 141), very acidic water is moving through the shallow alluvial aquifer and discharging to streams in the area. The resulting plume of contaminated ground water, which is about 11 miles long and about 2,000 feet wide (fig. $3 B$ ), contains more than $16,000 \mathrm{mg} / \mathrm{L}$ of dissolved solids. A sample of water from a well near Globe had a pH of 3.6 and concentrations of $10,800 \mathrm{mg} / \mathrm{L}$ sulfate, $3,000 \mathrm{mg} / \mathrm{L}$ iron, $150 \mathrm{mg} / \mathrm{L}$ copper, and $73 \mathrm{mg} / \mathrm{L}$ manganese.

Contamination of ground water by sulfates associated with copper mining in Cochise County is being studied by the U.S. Geological Survey. Ground water downgradient from a mine-tailings pond is contaminated with sulfate, ranging from 650 to $850 \mathrm{mg} / \mathrm{L}$ (G.R. Littin, U.S. Geological Survey, written commun., 1986). The presence of sulfate does not represent a health hazard but instead affects the esthetic quality of the water. The sulfate ion exerts a laxative effect following short-term exposure, and affects the taste and odor of drinking water. A maximum sulfate concentration of $250 \mathrm{mg} / \mathrm{L}$ is recommended on the basis of taste and odor consideration (U.S. Environmental Protection Agency, 1986d). Because the alluvial aquifer is the principal source of drinking water for the residents in Cochise County and is susceptible to contamination, the presence of sulfate could present a potential health concern.

\section{Urbanization}

In 1979, a study was begun of the chemical quality of water from urban runoff in Phoenix for the Maricopa Association of Governments (MAG). Sampling of runoff from storm drains showed that lead and other trace elements did not pose a threat to ground water (Schmidt, 1981, p. 21). Cadmium concentrations in the runoff water, however, were found to be greater than the EPA maximum contaminant levels of $0.010 \mathrm{mg} / \mathrm{L}$ for drinking water. Sampling of ground water in the area most likely to be affected by the urban storm runoff showed no contamination from this source during the study. Determinations of hydrocarbons were not made as part of this investigation, but other studies in the Western United States have shown that hydrocarbons in urban runoff may be a source of ground-water pollution.

A similar study in 1983 and 1984 in the Phoenix area addressed the effect of the use of dry wells for disposal of runoff from urban areas. Runoff entering dry wells at a commercial site contained large concentrations of total lead $(60-230 \mu \mathrm{g} / \mathrm{L}$, micrograms per liter), iron $(480-1,000 \mu \mathrm{g} / \mathrm{L})$, and manganese $(80-150 \mu \mathrm{g} / \mathrm{L})$, and small concentrations of diazinon (0.7-29 $\mu \mathrm{g} / \mathrm{L})$, dacthal (trace), and other hydrocarbons associated with plasticizers and paving materials. Analyses of ground water from monitor wells at the site, however, showed no evidence of contamination for the same constituents (Schmidt, 1985, p. 47).

\section{Waste Disposal}

Hazardous waste is treated, stored, or disposed of at five RCRA sites (fig. 3A). These wastes are a known or potential hazard to the quality of ground water, and the ADHS and the EPA have determined that ground water has been contaminated at several of these sites. Arizona currently has five EPA CERCLA (Superfund) sites (fig. $3 A$ ), and an additional four sites are proposed for inclusion in the Superfund program. Several hazardous-waste sites at six facilities also have been identified by the U.S. Department of Defense as part of their IRP as having potential for contamination. The purpose of the IRP is to identify and evaluate hazardous-waste disposal at military facilities and closely parallels the EPA's Superfund program under CERCLA. Phase-I studies-Installation Assessment and Records Search-have been completed at all eight IRP sites. Phase-II studies-Confirmation-have been completed or are being conducted at sites that require further study.
For purposes of this report, wastes are categorized into five major groups-light industry, mining, agricultural, municipal and county, and military. Most waste sites are in densely populated areas near Phoenix and Tucson (figs. $3 A$ and $3 C$ ). Waste sites commonly associated with light industry in Arizona are above and below ground storage tanks, lined and unlined ponds, and landfills. Wastes from these sites are mainly volatile organic compounds and trace metals, such as chromium, that are unique to the particular industry. Gasoline and solvents from leaking underground storage tanks have been documented in ground water at 11 locations in Arizona. Wastes from mine-tailings ponds are generally acidic and contain trace metals, such as copper, iron, manganese, and chromium. Acid, trace metals, sulfate, and cyanide from mining and metal-finishing activities contaminate ground water in many locations. Agricultural wastes consist mainly of nitrogen compounds and pesticides.

Municipal and county landfills sites are numerous, variable, and widespread throughout Arizona. Except for the sites in Phoenix and Tucson (fig. $3 C$ ), however, only a small amount of data has been collected to evaluate their effects on the quality of ground water. Military installations also have a wide variety of wastedisposal areas, including surface impoundments, evaporation ponds, active and buried landfills, and unlined sets for drying sludge from wastewater treatment. Even though the types of wastes are many, municipal, county, and military waste sites are contaminated mainly by volatile organic compounds, such as TCE and PCE.

\section{Potential for WATER-Quality Changes}

Ground-water studies throughout the State by agencies of the State and Federal governments have shown that the alluvial aquifers are subject to recharge from stream runoff as well as from evaporation ponds and other methods of waste disposal. Therefore, the potential for changes in the quality of water in these aquifers is significant. Monitoring and other efforts required by Arizona's recently enacted Environmental Quality Act, however, may help to prevent future contamination.

In 1983 the PAG developed a computer model to predict trends in ground-water quality in an area south of Tuscon and to project the effects that agriculture, mining, and wastewater treatment and disposal might have on water quality. Using future conditions considered most likely, the model indicated that contributions of nitrate (as nitrogen) from agriculture to ground water would decrease and that percolation of treated effluent to the water table would have a localized effect. The model also indicated that, in the absence of mitigation, contaminant plumes from copper-mine tailing ponds in the area would eventually contaminate local drinking-water supplies (Pima Association of Governments, written commun., 1983).

\section{GROUND-WATER-QUALITY MANAGEMENT}

The Arizona Environmental Quality Act of 1986 established a Department of Environmental Quality (ADEQ) to administer State programs on water quality, air quality, solid waste, and hazardous waste beginning July 1, 1987. ADHS will develop and implement programs during the 1986 fiscal year (May 1986 through June 1987); thereafter, these programs will be transferred to the new department. as follows:

The general provisions of the Environmental Quality Act are

1. Establish an aquifer classification and aquifer protection permit program. Under this program, the Director of ADEQ is required to identify and define boundaries of all aquifers in the State, adopt new water-quality standards, develop programs to control point-source and nonpoint-source discharges to surface water, develop permit programs for aquifer protection and underground-injection control, require monitoring, and adopt other rules as necessary to enforce the law. 
2. Establish aquifer reclassification processes.

3. Authorize filing of citizen suits for violation of environmental-quality standards.

4. Establish maximum civil penalty of $\$ 25,000$ per day per violation and criminal classifications for certain violations.

5. Establish the Water Quality Assurance Revolving Fund for environmental cleanup.

6. Abolish the Board of Pesticide Control and transfer the responsibilities to three agencies-the Commission of Agriculture and Horticulture, the Industrial Commission, and the Department of Environmental Quality.

7. Establish the following advisory bodies, boards, and committees:

(a) Water Quality Advisory Council,

(b) Agricultural Best Management Practices Advisory Committee on Nitrogen Fertilizer and a Committee on Concentrated Animal Feeding Operations,

(c) Water Quality Appeals Board,

(d) Joint Legislative Committee on Water Quality Assurance Revolving Fund Revenues, and

(e) Joint Legislative Pesticide Oversight Committee.

8. Require annual reports to the Governor and Legislature on

(a) pesticide-control activities,

(b) well-sampling activities, and

(c) violations and enforcement of water-quality and hazardous-waste-disposal standards. Require a report every 5 years on contaminant levels in aquifers and the effects of regulation and bestmanagement practices.

9. Require the Auditor General to contract for an independent performance review to be conducted in fiscal year 1989 on the regulatory program established by this Act.

\section{SELECTED REFERENCES}

Anderson, T.W., 1980, Study plan for the regional aquifer-system analysis of alluvial basins in south-central Arizona and adjacent States: U.S. Geological Survey Open-File Report 80-1197, 22 p.

Arizona Department of Health Services, 1986, State of Arizona water quality assessment for water years 1984 and 1985 (Section 305b): Arizona Department of Health Services report, $116 \mathrm{p}$.

1985-86, Groundwater quality update: Arizona Department of Health Services (published quarterly).

Cooley, M.E., 1963, Hydrology of the Plateau uplands province, in White, N.D., Stulik, R.S., Morse, E.K., and others, Annual report on ground water in Arizona, spring 1962 to spring 1963: Arizona State Land Department Water Resources Report No. 15, 136 p.

Envirologic Systems, Inc., 1983, Mining activities and water-quality report: Florence, Central Arizona Association of Governments Mineral Extraction Task Force Report METFN7, 142 p.

Eychaner, J.H., and Stollenwerk, K.G., 1985, Neutralization of acidic ground water near Globe, Arizona, in Schmidt, K.D., ed., Symposium on ground water contamination and reclamation, Tucson, Arizona, August 14-15, 1985, Proceedings: American Water Resources Association, August 1985, p. 141-148.

Kister, L.R., 1973, Quality of ground water in the lower Colorado River Region, Arizona, Nevada, New Mexico, and Utah: U.S. Geological
Survey Hydrologic Investigations Atlas HA-478, scale 1: 1,000,000, 2 sheets.

Kister, L.R., Brown, S.G., Schumann, H.H., and Johnson, P.W., 1966, Maps showing fluoride content and salinity of ground water in the Willcox Basin, Graham and Cochise Counties, Arizona: U.S Geological Survey Hydrologic Investigations Atlas HA-214, scale $1: 250,000,2$ sheets.

Mann, L.J., White, N.D., and Wilson, R.P., 1978, Maps showing groundwater conditions in the Willcox area, Cochise and Graham Counties, Arizona-1975: U.S. Geological Survey Water-Resources Investigations Report 78-60, scale, 1:250,000, 2 sheets.

Pima Association of Governments, 1983a, Assessment of nitrate in groundwater of the upper Santa Cruz basin: Tucson, Ariz., Upper Santa Cruz Basin Mines Task Force, $120 \mathrm{p}$.

1983b, Ground-water monitoring in the Tucson copper mining district: Tucson, Ariz., Upper Santa Cruz Basin Mines Task Force, $117 \mathrm{p}$.

Robertson, F.N., 1986, Occurrence and solubility controls of trace elements in ground water in alluvial basins of Arizona, in Anderson, T. W., and Johnson, A. I., eds., Regional Aquifer Systems of the United States, Southwest Alluvial Basins of Arizona: American Water Resources Association Monograph Series No. 7, p. 69-80.

Robinson, Priscilla, 1986, The environmental quality act of 1986-It's a new water quality law-and a whole lot more, in Water words: Southern Arizona Water Resources Association, v. 4, no. 3, p. 1-7.

Schmidt, K.D., 1981, Results of the initial groundwater quality monitoring phase-November 1979-January 1981: Maricopa Association of Governments duplicated report, $22 \mathrm{p}$.

1985, Results of dry well monitoring project for a commercial site in the Phoenix urban area: Maricopa Association of Governments duplicated report, $62 \mathrm{p}$.

U.S. Department of Defense, 1986, Status of the Department of Defense Installation Restoration Program-Information paper: Washington, D.C., U.S. Department of Defense, Office of the Assistant Secretary of Defense (Acquisition and Logistics), Environmental Policy Directorate, February, $35 \mathrm{p}$.

U.S. Environmental Protection Agency, 1986a, Maximum contaminant levels (subpart B of part 141, national interim primary drinking-water regulations): U.S. Code of Federal Regulations, Title 40, parts 100 to 149 , revised as of July 1,1986 , p. 524-528.

$1986 \mathrm{~b}$, Secondary maximum contaminant levels (section 143.3 of part 143, national secondary drinking-water regulations): U.S. Code of Federal Regulations, Title 40, Parts 100 to 149, revised as of July 1,1986 , p. $587-590$.

1986c, Amendment to National Oil and Hazardous Substances Contingency Plan; national priorities list, final rule and proposed rule: Federal Register, v. 51, no. 111, June 10, 1986, p. 21053-21112. 1986d, National priorities list fact book-June 1986: U.S. Environmental Protection Agency, Office of Emergency and Remedial Response, report HW-7.3, $94 \mathrm{p}$.

U.S. Geological Survey, 1985a, Annual summary of ground-water conditions in Arizona, spring 1983 to spring 1984: U.S. Geological Survey Open-File Report 85-410, scale 1: 250,000, 2 sheets.

$1985 \mathrm{~b}$, National water summary $1984-$ Hydrologic events, selected water-quality trends, and ground-water resources: U.S. Geological Survey Water-Supply Paper 2275, 467 p.

Upper Santa Cruz Basin Mines Task Force, 1979, Upper Santa Cruz groundwater quality baseline report: Arizona Department of Health Services, v. 1 and v. 2, 117 p.

Prepared by Lester R. Kister, Dean B. Radtke, U.S. Geological Survey, and Chuck Graf, Arizona Department of Health Services.

FOR ADDITIONAL INFORMATION: District Chief, U.S. Geological Survey, 300 W. Congress, FB 44, Tucson, AZ 85701-1393. 

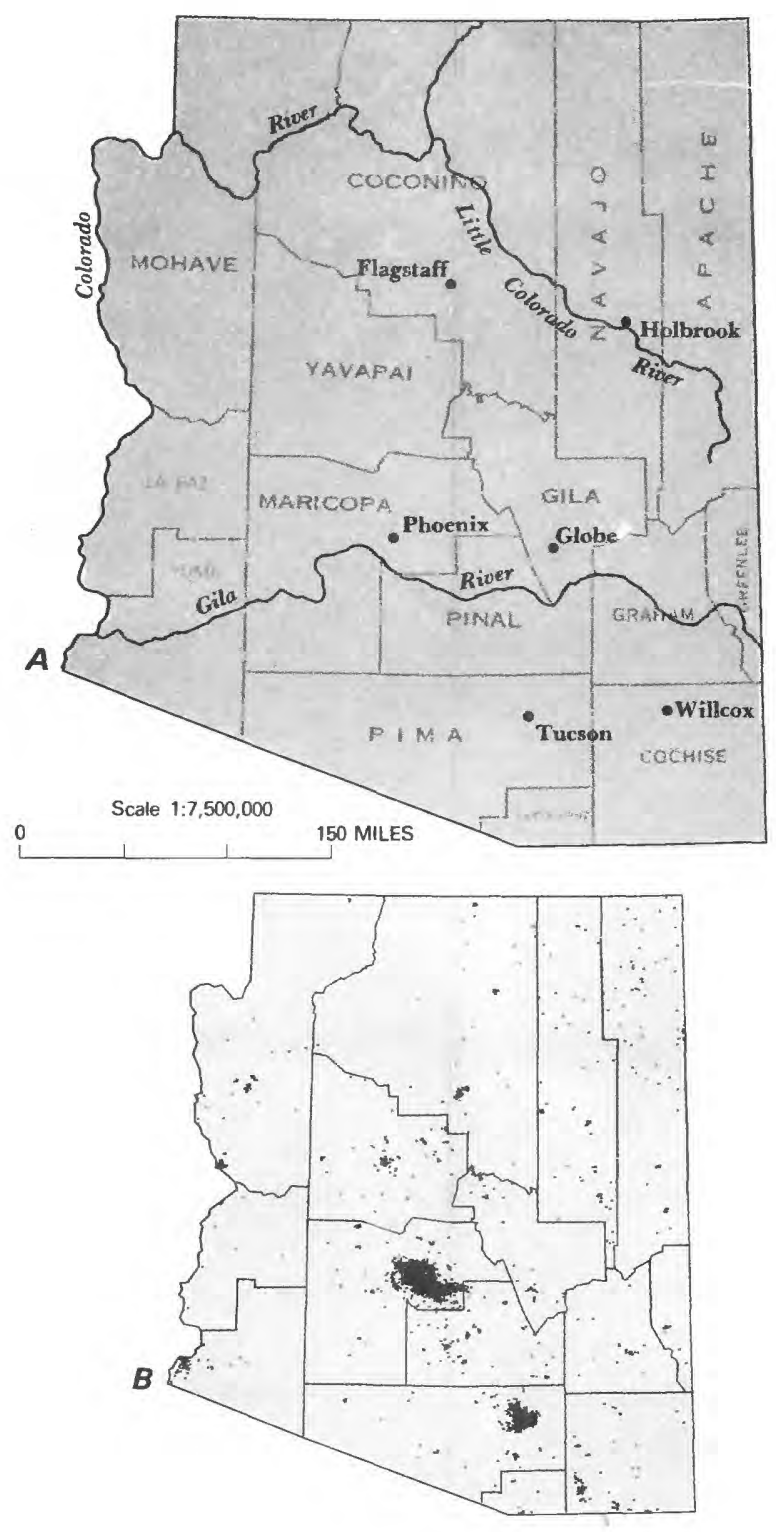

Figure 1. Selected geographic features and 1985 population distribution in Arizona. $A$, Counties, selected cities, and major drainages. $B$ Population distribution, 1985; each dot on the map represents 1,000 people. (Source: B, Data from U.S. Bureau of the Census 1980 decennial census files, adjusted to the 1985 U.S. Bureau of the Census data for county populations.1 
PRINCIPAL AQUIFER AND SUBDIVISIONS

Numeral is basin number in figures $2 A 2$ and $2 C$

Alluvial aquifers (1-10) - Locally may include

evaporite deposits and volcanic rocks

Colorado River basin (1) - Hoover to Imperial Dams

Yuma Valley basin (2)

Lower Santa Cruz River Valtey basin (4)

San Simon Wash basin (5)

Avra Valley basin (6)

Upper Santa Cruz River basin (8)

Safford basin (9)

Sandstone aquifers (11-13)

Concho basin (11)

Concho basin (11)

San Franc

(Navajo Sandstone)

Badrock aquifers

- Water-province boundary

- Ground-water basin boundary

- Area of major ground-water withdrawals

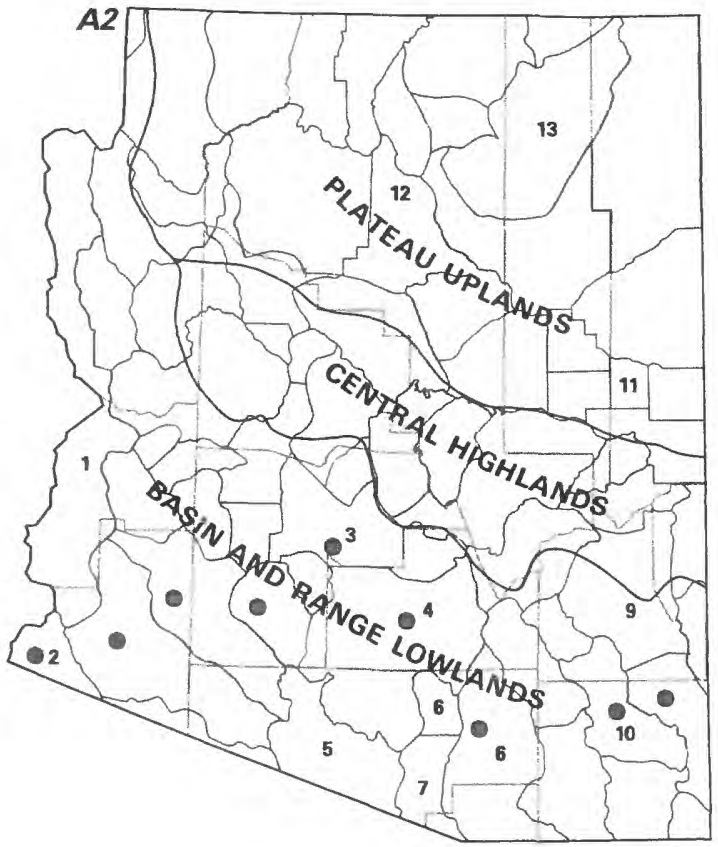

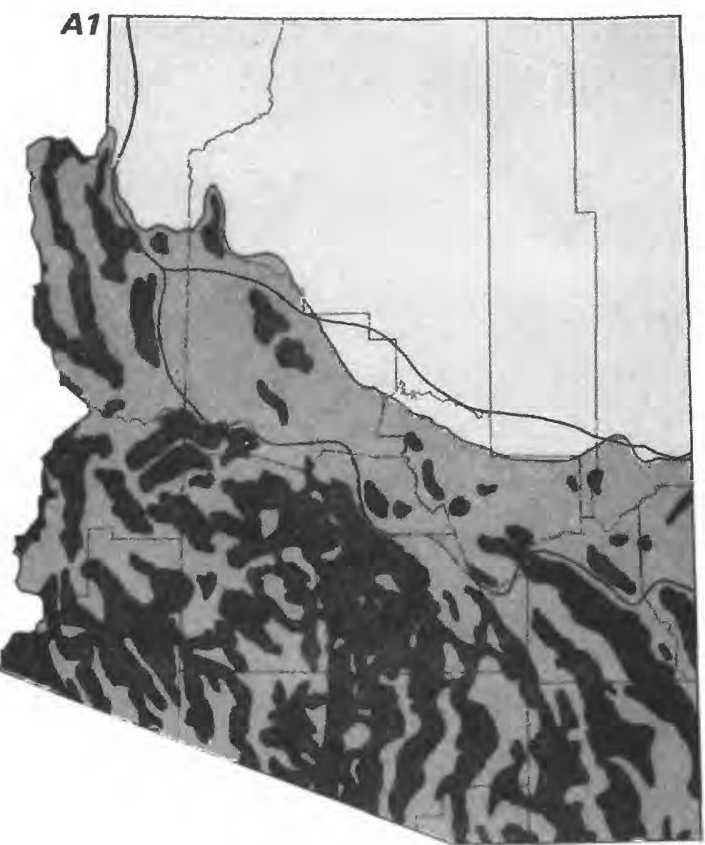

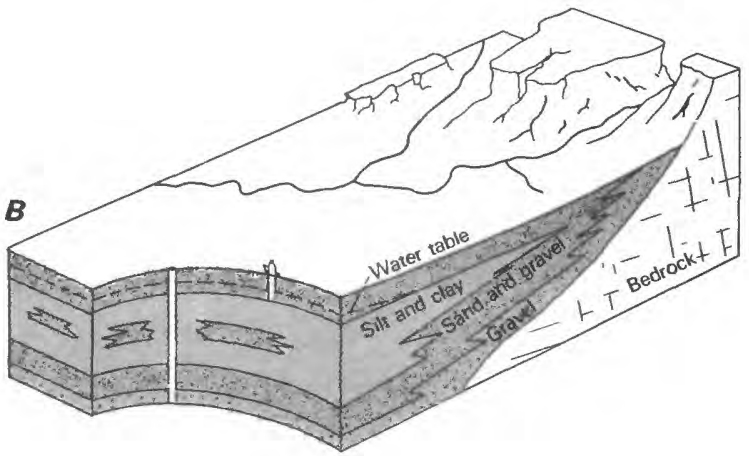

NUMBER OF ANALYSES

C WATER-QUALITY DATA

Percentile - Percentage of analyses equal to or less than indicated values

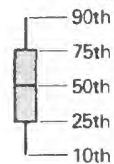

National drinking-water standards Maxmum permissible contaminan level (primary)

- _ - Maximum recommended contaminant level (secondary)

Reporting limit

Minimum reporting level with analytical method used

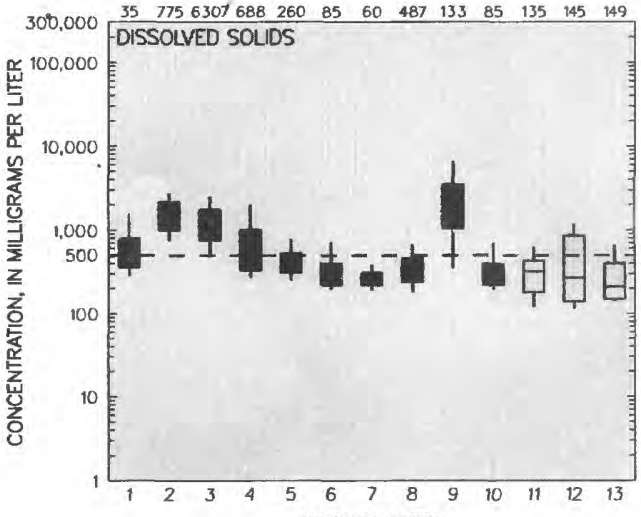

NUMBER OF ANALYSES

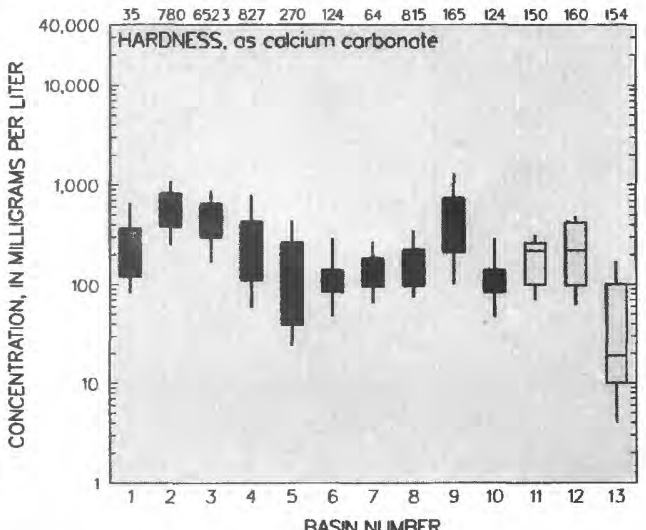

Figure 2. Principal aquifers and related water-quality data in Arizona. A1, Principal aquifers. A2, Water provinces, ground-water basins, and areas of major ground-water withdrawals. B. Generalized block diagram. $C$. Selected water-quality constituents and properties, as of 1965-85. (Sources: $A 1$, Anderson, 1980; Cooley, 1963. A2, U.S. Geological Survey, 1985a,b. B. Compiled by N.D. White and T.W. Anderson from U.S. Geological Survey files. C. Analyses compiled from U.S. Geological Survey files; national drinking-water standards from U.S. Environmental Protection Agency, 1986a,b.) 

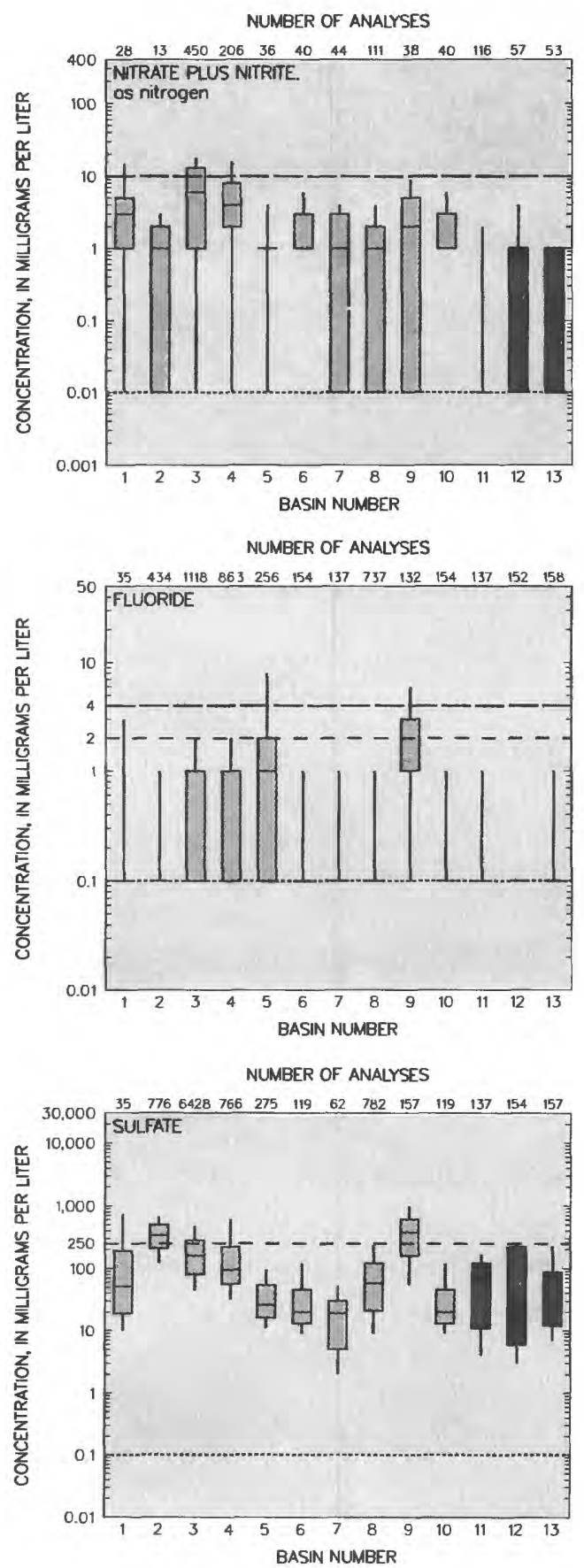

Figure 2.-Continued. 


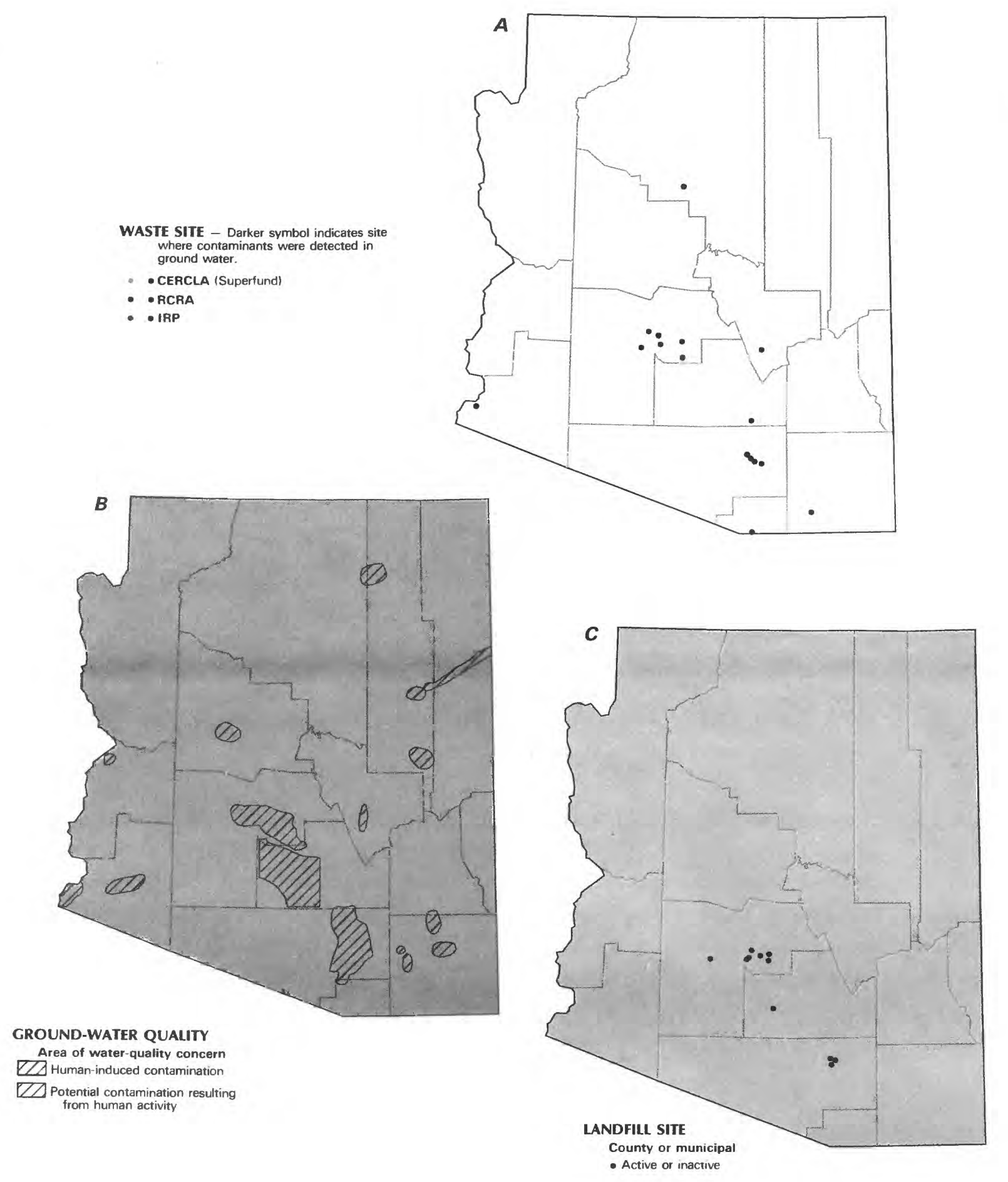

Figure 3. Selected waste sites and ground-water-quality information in Arizona. A. Comprehensive Environmental Response, Compensation, and Liability ACt (CERCLA) sites, as of January 1, 1987; Resource Conservation and Recovery ACt (RCRA) sites, as of January 1, 1987; Department of Defense Installation Restoration Program (IRP) sites, as of January 1, 1987. B. Areas of human-induced and potential contamination as of January 1, 1987. C, County and municipal landfills, as of January 1, 1987. (Sources: $A, B, C$, Arizona Department of Health Services, 1986.) 